\title{
Research on the Construction and Application of College English Mixed Teaching Mode Based on MOOC
}

\author{
Zhentan Li* \\ Nanning University, Nanning, Guangxi, 530004, China
}

\begin{tabular}{l} 
ARTICLE INFO \\
Article history \\
Received: 16 March 2021 \\
Revised: 23 March 2021 \\
Accepted: 9 April 2021 \\
Published Online: 16 April 2021 \\
\hline
\end{tabular}

Keywords:

MOOC

Hybrid teaching

College English

\begin{abstract}
The current MOOC platform gradually enters the college classroom, which has a great impact on improving the quality and efficiency of classroom teaching in colleges and universities. This paper mainly introduces the meaning and content of MOOC and the related teaching mode, and introduces its development and characteristics. In view of the shortcomings of the current MOOC platform courses and the problems existing in the hybrid teaching, the two are fully combined to propose a hybrid teaching mode based on MOOC. This kind of teaching mode is discussed. Taking the college English class as an example, the analysis is carried out from the teaching object to discuss whether the teaching mode is in line with the current teaching development. From the aspects of curriculum structure setting, teaching resource construction and teaching design, it is analyzed how to implement this teaching mode better in the teaching of college English. Further guidance and optimization of MOOC application in college English teaching, and the application of MOOC-based hybrid teaching mode in teaching.
\end{abstract}

of Online Open Courses in Colleges and Universities" to promote the construction and application of MOOC resources. "The Teaching Requirements for College English Courses" states that "the goal of college English teaching is to develop students' comprehensive English application ability, especially the ability of listening and speaking, while enhancing their independent learning ability and

*Corresponding Author:

Zhentan $\mathrm{Li}$,

Male, Zhuang nationality, master, lecturer of Nanning University;

Research direction: foreign language teaching;

Nanning University, Nanning, Guangxi, 530004, China;

E-mail:328458543@qq.com.

Fund Project:

This paper is one of the research results of the "Research on the Construction and Application of College English Mixed Teaching Mode Based on MOOC" of the 2018 Professor Cultivation Project of Nanning University(2018JSGC13) and Research on the "Online and Offline" Mixed "Teaching Mode of College English Listening and Speaking Course Based on U Campus Intelligent Teaching Cloud Platform "of Education Reform Project of Nanning University in 2019 (2019XJJG04) and Teaching Team Construction Project of College English Course of Nanning University in 2017 (2017XJJXTD05). 
improving their comprehensive cultural accomplishment. College English curriculum design should fully consider the requirements of listening and speaking ability training, use advanced information technology, develop and construct various computer network-based courses, and provide students with a good language learning environment and conditions."

The current need for educators to explore the following issues:

(1) How to achieve deep integration of information technology and college English listening and speaking courses.

(2) How to build a mixed teaching mode based on MOOC for college English listening and speaking courses.

(3) How to better develop the English communication skills of non-English majors.

\section{The Necessity of Carrying out Mixed Teaching in College English Listening and Speaking Courses}

In the teaching of "College English", although teachers can develop their listening and speaking ability according to their English foundation and employment needs, the teaching mode that is restricted by many parties' leads to unsatisfactory teaching results, and students' listening and speaking skills are slow. First of all, the "College English" course is taught in large classes, with an average of more than 50 students. Only a few students can get the opportunity to practice speaking in the classroom. It is difficult for teachers to provide timely oral guidance and feedback to each student. In addition, the "College English" course is continuously compressed, and the teaching and speaking can only be completed within a fixed time, which hinders the improvement of teaching effect. In addition, the content of the "College English" course is mainly based on teaching materials. Although teachers' pay attention to the supplement of teaching resources, the content is not rich enough and personalized, which can not fully stimulate students' interest in learning, which is not conducive to cultivating students' independent learning ability ${ }^{[1]}$.

\section{The theoretical basis of the mixed teaching mode of college English listening and speak- ing course based on MOOC}

\subsection{Constructivism Theory and Humanism Theory}

Constructivist learning theory emphasizes the subject and center of students. Teachers are teaching instructors, focusing on the design of teaching environment, teaching situation and independent learning strategies. Teachers are not the imparters of knowledge, but guide, guide and help students to explore and construct knowledge systems on their own; students are not passive knowledge recipients, but active knowledge constructors. The constructivist learning theory believes that knowledge is dynamic, and teachers should provide learners with systematic and rich learning resources as much as possible, and focus on cultivating students' learning autonomy. MOOC meets the requirements of constructivism for the learning process.

The humanistic learning theory focuses on exploring the potential of students. It advocates that the design and implementation of teaching activities is centered on students, emphasizing the influence of emotions on students' cognition and learning. Teachers need to pay attention to the importance of students' emotions, pay attention to teaching students in accordance with their aptitude, and promote and influence each other.

\subsection{Situational Cognitive Theory}

Situational cognition theory argues that practice and learning are not independent; meaning is not separated from practice and context, but is negotiated in practice and context. The interaction between knowledge and action, knowledge has context, is a state of construction in the process of interaction between individuals and the environment. Language is a tool of communication. English words, phrases and sentences are not isolated, but exist in specific situations and communication ${ }^{[2]}$. Improving English listening and speaking ability is inseparable from rich communication situations. The MOOC-based college English listening and speaking curriculum is a blended teaching model that provides students with real language learning scenarios through lively video and life scenarios.

\section{MOOC-Based Mixed Teaching Mode of Col- lege English Listening and Speaking Course}

\subsection{Teaching Design Strategy}

\subsubsection{Learning Emotional Strategies}

Studies have shown that emotional factors have a crucial impact on language learning. The uniqueness of the language learning process triggers language anxiety, which is a combination of self-awareness, beliefs, feelings, and behaviors in the classroom language learning process. Students will develop psychological anxiety in English learning, especially anxiety and fear in listening and speaking, such as sense of loss of control and unpredictability during audio input, fear of expression and lack of self-confidence. Therefore, MOOC-based mixed 
teaching of college English listening and speaking courses requires the use of emotional strategies to guide students. First of all, educators need to consider the characteristics of students when making MOOCs, including lack of basic knowledge, lack of motivation for learning, lack of interest, lack of self-confidence, and foster students' easy and active learning emotions with a sincere communication attitude and language. Secondly, the teaching of MOOCbased courses needs to change the idea of hierarchical teaching. Teachers need to fully understand the role of individuals in mixed teaching in the process of listening and speaking ${ }^{[3]}$. The initiative of the activity and the test of the MOOC learning effect are given to the students, so that the students can subjectively recognize the initiative of the communication, become the participants of the offline activities, and change the thinking of correcting mistakes in the classroom teaching. At the same time, teachers can communicate and communicate with students online through the MOOC platform, thus alleviating the tension of students during face-to-face communication.

\subsubsection{Organizational Strategy of Teaching Con- tent}

Compared with the traditional single-mode college English listening and speaking course teaching, the MOOCbased college English listening and speaking curriculum has a richer and more systematic teaching content based on daily oral scenes, workplace communication needs and so on.

Teachers need to record real scene communication videos on MOOC for students to watch, simulate the dialogue between English national life and work scenes, and create an authentic English learning environment. In addition, teachers need to provide expanded content on the platform, such as language exchange materials, cultural knowledge, etymology, Anglo-American profiles and history in English-speaking countries. In the classroom teaching, teachers need to check the learning effect of the listening and speaking content according to the different conditions of the profession and the class. Focus on the listening and speaking practice based on peer collaboration in the classroom ${ }^{[4]}$.

\subsubsection{Strategy for the Development of Teaching Activities}

With the support of network technology and information technology, students can strengthen their language skills through online platforms, engage in life-long interactions and teacher-student interactions, and then demonstrate what they learn through classrooms (or networks).
MOOC-based college English listening and speaking curriculum can be divided into three modules to carry out activities, namely MOOC platform online activities, classroom teaching activities and after-school activities ${ }^{[5]}$. First of all, the MOOC platform online learning activities are based on platform-based system design, which can promote students' independent learning and collaborative learning. Students can choose the time, place, method and progress of the learning on the MOOC platform. They can display MOOC learning activities according to the exercises, online communication activities and learning results provided by the online system. Online listening and speaking meets the characteristics of personalized learning, and realizes the combination of independent learning and cooperative learning. Students can explore learning problems and share learning outcomes through a web platform. Secondly, in the classroom activities, teachers can arrange personal reports, group reports, situational performances and other activities, adopt the flipping classroom teaching mode, and also carry out targeted teaching according to the basic situation of the students ${ }^{[6]}$. When teachers develop listening and speaking activities, they should pay attention to the main body of students, so that students become the center of listening to classroom teaching activities. Finally, the after-school activities are mainly fun activities, aiming at creating a relaxed atmosphere of English listening and speaking practice, and encouraging students to carry out after-school activities in the bedroom ${ }^{[7]}$.

\subsection{Learning Evaluation Method}

The mixed teaching based on MOOC for college English listening and speaking courses should follow the principle of combining online and offline, student self-assessment/mutual evaluation and teacher evaluation. A hybrid learning evaluation method is combined to combine dynamic formative evaluation with final assessment ${ }^{[8]}$. Students are encouraged to use the MOOC platform to improve their English listening and speaking skills. The online evaluation section is based on data from the MOOC platform to evaluate students, including online learning, practice, and communication records, to achieve a combination of student self-assessment and online evaluation. Students will get corresponding test questions during the MOOC learning process or after completing a module learning content; Online discussion and classroom teaching mainly adopt student mutual evaluation and teacher evaluation methods, based on students' learning attitude, performance in classroom activities, participation in classroom and group activities, and listening and speaking tests; After-school development activities still need to 
record the performance of students and evaluate them, focusing on the dynamics of the evaluation process and the diversity of evaluation methods ${ }^{[9]}$.

\section{Conclusion}

The mixed teaching mode of college English listening and speaking course based on MOOC solves the problem of completing students' listening and speaking training in limited class hours, which helps to improve students' listening and speaking skills and mobilize learning enthusiasm, and create a personalized learning environment. In order to construct a mixed teaching mode of college English listening and speaking based on MOOC in colleges and universities, this study makes a preliminary exploration from the aspects of learning emotional strategy, teaching content organization strategy, teaching activity development strategy and learning evaluation method. This not only provides ideas for future in-depth research and teaching practice, but also strengthens the cultivation of students' English communication skills.

\section{References}

[1] Shen C W, Kuok C J. Learning in massive open online courses: Evidence from social media mining[J]. Computers in Human Behavior, 2015, 51(10):568577.

[2] S.A. Chapman, S. Goodman, J. Jawitz, et al. A strategy for monitoring and evaluating massive open online courses $[\mathrm{J}]$. Evaluation and Program Planning,2016, 57(08):55-63.
[3] Edgar Bernad-Mechó. A Multimodal Discourse Analysis of Linking Metadiscursive Elements in Two Opencourseware Lectures (MOOCs) [J]. Procedia Social and Behavioral Sciences, 2015, 212:61-66.

[4] Andreas M. Kaplan, Michael Haenlein. Higher education and the digital revolution: About MOOCs, SPOCs, social media, and the Cookie Monster[J]. Business Horizons, 2016, 59(4):441-450.

[5] Fatiha Bousbahi, HendaChorfi.MOOC-Rec: A Case Based Recommender System for MOOCs [J]. Procedia - Social and Behavioral Sciences, 2015(195):1813-1822.

[6] Alice Barana, Alessandro Bogino, Michele Fioravera, et al. Digital Support for University Guidance and Improvement of Study Results [J]. Procedia - Social and Behavioral Sciences, 2016, 228:547-552.

[7] Liqiang Huang, Jie Zhang, Yuan Liu. Antecedents of student MOOC revisit intention: Moderation effect of course difficulty[J]. International Journal of Information Management, 2017, 37(2):84-91.

[8] Alvin Vista, Esther Care, Patrick Griffin. A new approach touching marking large-scale complex assessments: Developing a distributed marking system that uses an automatically scaffolding and rubric-targeted interface for guided peer-review [J]. Assessing Writing, 2015, 24:1-15.

[9] Valerie Swigart, Zhan Liang.Digital resources for nursing education: Open courseware and massive open online courses[J]. International Journal of Nursing Sciences, 2016, 3( 3):307-313. 